\section{The Oblong or Truncate-tailed Ocean Sunfish, Ranzania truncata, at Mauritius}

IN studying the history and distribution in the three great oceans of the very rare pointed-tailed sunfish Masturus, I have had to disentangle it in the literature from the other two genera of the family Molidæ-Mola, the round-tailed genus, and Ranzania, the truncate form. The former, known since Roman times, is found in the three central oceans, but to my surprise, Ranzania, while recorded from the Atlantic and Pacific, has seemingly never been described from the Indian Ocean. However, there is known to me an unpublished figure and description of it in this ocean and it seems well to put these on record.

Nicolas Pike was U.S. Consul at Port Louis, Mauritius, from 1867 until 1874. During these years, he made extensive natural history collections, drawings and studies and brought back to New York in 1874 eight volumes of drawings of fishes, most of them in colour. In 1905, these were purchased by J. Pierpont Morgan and presented to the library of the American Museum of Natural History. Finding these among our treasures, I published in 1929 a sketch of Pike's life and an analysis and description of his 486 paintings ${ }^{1}$ of fishes. These I listed alphabetically under the name of the fish. Number 324 is his "Orthagoriscus truncatus Retz; molle, poisson lune". The figure is noted as made from a stuffed specimen in the little museum at Port Louis, June 25, 1873 , and is found on pl. 8 of vol. 6 .

This figure is somewhat crude but plainly that of Ranzania truncata in its oblong form, truncate tail, in the relative positions and conjunction of dorsal, caudal and anal fins; in the presence of bars on the lower side of the head as far back as the pectoral fin; and in the imperfect markings on the hinder part of the side with some few on the dorsum. Here is Pike's brief and untechnical description.

\section{Sunfish-Creole Molle}

Height of body less the half total length. Skin very smooth, divided on back into small hexagonal scutella [drawing of one with dots] - only the raised dots visible elsewhere. It appears to have been marked nearly all over with lines, blots and dots but so effaced I can only trace what are shown in sketch. $I$ think the broad stripe on bare part in front of $D$ was yellow, also stripes between lines; but where I have put large round spots, they were either white or yellow with a dark center. The entire color is a grey brown now. Snout round-a dark boss of sorne kind above snout, a deep hollow for $\mathrm{P}$ behind them -2 have scutes in front.

Numbers [of fin rays] about D 15 or $16-\mathrm{A} 15$ or $16-\mathrm{C} 23$ or $4, \mathrm{P} 12$. Above boss on head is a rise and beyond a depression (rough sketch) along back at top.

This figure and description made sixty-two years ago constitute the first and only record known to me of the presence of the oblong sunfish in the Indian Ocean. Thinking that Barnard might have a record of it for South Africa, I consulted his "Monograph". . In this he lists three specimens in the South African Museum, from False Bay, Table Bay and Dassen Island-all to the west of Cape Agulhas, through which runs the meridian dividing the Indian and Atlantic Oceans.
Ranzania is an inhabitant of warm seas, and this is very far south for it. The average latitude for the three localities is about $34^{\circ} \mathrm{S}$. and the mean annual temperature is about $60^{\circ} \mathrm{F}$. This is cold water for this sunfish and hence one may judge that Ranzania is not endemic in Cape waters. Add to this the fact that it is an exceedingly poor swimmer and hence could scarcely have reached South Africa by its own locomotive powers, then how did it come to these parts?

The answer is to be found in the currents in the western Indian Ocean. Ranzania is found at Mauritius, in the path of the Southwest Drift of the Equatorial Current of this ocean. In about lat. $30^{\circ} \mathrm{S}$., this drift unites with the Mozambique Current to form the Agulhas Current, which sweeps around the Cape of that name, and turns north-westward around the Cape of Good Hope.

In my judgment, Ranzania was brought from Mauritius or elsewhere in the western Indian Ocean by these currents to South Africa, and, since False and Table Bays act as natural traps for the back-wash of the current as it sweeps west and north-west, these specimens were thus stranded. These three captures of Ranzania in South Africa are to me so many additional proofs of its occurrence in the western Indian Ocean.

American Museum of Natural History, E. W. GUdGer.

New York City. Feb. 11.

${ }^{1}$ Gudger, E. W., "Nicolas Pike and his unpublished Paintings' of the Fishes of Mauritius, Western Indian Ocean, with an Index to the Fishes." Bull. Amer. Mus. Nat. Hist., 58, 489-530, 8 text-figs ; 1929. - Barnard, K. H., A Monograph of the Marine Fishes of South Africa (Ranzania truncata, pp. 989-990, text-fig. 32), Ann. S. African Mus., 21; 1927 .

\section{Diffusion of Hydrogen through Aluminium}

The solubility of hydrogen in aluminium has been determined by Sieverts ${ }^{1}$, Röntgen and Braun ${ }^{2}$, and Röntgen and Moller ${ }^{3}$. These authors agree that the gas is completely insoluble in the solid metal at all temperatures below the freezing point. There are certain difficulties in the direct determination in this case, and we have therefore attempted to detect the diffusion of hydrogen through the solid metal. The method used is that described in a recent paper.

We find that hydrogen diffuses through aluminium at a rate which is easily measurable above $400^{\circ} \mathrm{C}$. Preliminary measurements show that it follows the usual diffusion law with regard to the effects of temperature and pressure, namely,

$$
D=k \sqrt{ } P . e^{-b / T},
$$

$b$ having a value of about 14,000 . The rate of diffusion at $400^{\circ}-600^{\circ} \mathrm{C}$. is of the same order as that of hydrogen through copper, but the temperature coefficient is much larger. We hope later to publish exact data.

The fact that hydrogen can diffuse through solid aluminium shows that it must be soluble, but does not indicate the degree of solubility.

\section{SMTTHELIS.}

Research Laboratories of the

$$
\text { C. E. Ranstey. }
$$

General Electric Company Ltd., Wembley. March 8

${ }^{1} Z$. Electrochem., 16, 707; 1910.

Metallwirtschaft., 11, $459 ; 1932$

3 ibid., 13, 81 and $97 ; 1934$.

- Proe. Roy. Soc. in the press. 